\title{
MASALAH CINA, MASALAH CINTA: POSISI ORANG TIONGHOA DALAM DI KAKI BUKIT CIBALAK KARYA AHMAD TOHARI
}

\author{
Christopher Woodrich \\ S2 Ilmu Sastra, Fakultas Ilmu Budaya Universitas Gadjah Mada \\ Jln. Sosiohumaniora, Bulaksumur, Yogyakarta \\ Email: chris_woodrich@hotmail.com
}

\begin{abstract}
Abstrak
Selama Orde Baru (1966-98), posisi warga negara Indonesia keturunan Tionghoa dianggap penuh dengan masalah: mereka bukan Pribumi, tetapi juga bukan sepenuhnya Tionghoa. Jawaban atas "Masalah Cina" ini dipaparkan oleh pelbagai pembicara dan penulis, termasuk pengarang karya sastra. Dalam Di Kaki Bukit Cibalak (1977), Ahmad Tohari memaparkan dua tokoh Tionghoa, yaitu Nyonya Wibawa dan Mulyani, yang pertama sebagai majikan dan yang kedua sebagai kekasih dari tokoh utama Pambudi. Dengan menerapkan teori strukturalisme genetiknya Goldmann, ditemukan bahwa melalui pencitraan watak dan fisik kedua tokoh Tionghoa dalam novel ini, Tohari mempromosikan paham pembauran sebagai satu-satunya cara untuk menjawab masalah Cina (kalaupun memang bisa dijawab): dikotomi antara orang Tionghoa dan orang Pribumi harus dihapus. Meskipun demikian, Tohari tetap membedakan orang Tionghoa dengan memposisikan mereka sebagai pihak yang hanya bertindak demi kebaikan orang Pribumi.
\end{abstract}

Kata Kunci: "Masalah Cina", Ahmad Tohari, posisi orang Tionghoa, Di Kaki Bukit Cibalak

\begin{abstract}
For the duration of the New Order era (1966-98), the position of Chinese Indonesians was considered a problematic question: they were not "Pribumi" (native), but also not entirely Chinese. This "Chinese Problem" was discussed by a variety of speakers and writers, including several authors of literary works. In Di Kaki Bukit Cibalak (1977), Ahmad Tohari presents two ethnic Chinese characters, Nyonya Wibawa and Mulyani, the first as the employer and the second as the lover of the main character, Pambudi. By applying Goldmann's theory of genetic structuralism, we show that through his depiction of the physical and behavioural aspects of the characters, Tohari promotes an assimilationist approach as the only possible solution to the Chinese problem (if it can be solved): the dichotomies between ethnic Chinese and Native Indonesians must be erased. However, Tohari continues to differentiate the ethnic Chinese by positioning them as persons who must only act to support the welfare of the Pribumi.
\end{abstract}

Keywords: "The Chinese Problem", Ahmad Tohari, position of Chinese Indonesians, Di Kaki Bukit Cibalak

\section{Pendahuluan}

Pada awal abad ke-20, penduduk Nusantara yang berketurunan Tionghoa (selanjutnya disebut 'orang Tionghoa') memiliki posisi yang jelas terpisah dari orang-orang Pribumi; sistem sekolahan dan kekerabatan kedua kelompok ini jarang bercampur, dan pengarang Tionghoa terus memperjuangkan identitas etnis mereka sebagai orang Tionghoa. Dalam belasan tahun awal setelah kemerdekaan Indonesia, mulai muncul pertanyaan mengenai identitas orang Tionghoa, yaitu apakah mereka bisa dihitung sebagai orang Indonesia. Meskipun pertanyaan itu sudah muncul, dan ada hukum yang berkaitan dengan kewarganegaraan orang Tionghoa, masalah ini tidak dipusatkan oleh pemerintah ataupun menjadi polemik yang terlalu luas.

Baru setelah Presiden Soeharto mulai menjabat pada tahun 1966, "Masalah Cina" ini menjadi suatu persoalan yang ramai dibicarakan. Posisi pemerintah, yang terwujud dalam pelbagai undang-undang, bersifat ambigu: ada usaha untuk "mengindonesiakan" orang Tionghoa dengan menghapus perbedaan, misalnya melalui Instruksi Presiden No. 14/1967 yang melarang penggunaan aksara Tionghoa, sekaligus membedakan etnis tersebut 
dengan memperlakukan mereka secara berbeda dari orang Pribumi, misalnya melalui kewajiban agar orang Tionghoa memiliki Surat Bukti Kewarganegaraan Republik Indonesia. Dialog dalam masyarakat pada umumnya mengambil dua sudut pandang yang berlawanan, yaitu sudut pandang yang mendukung pembauran etnis Tionghoa dengan kebudayaan nasional dan sudut pandang yang mendukung pelestarian identitas kebudayaan Tionghoa (Tan, 2008: 182). Tokoh-tokoh Tionghoa yang muncul di tingkat nasional pada periode tersebut cenderung menolak tradisi Tionghoa dan sepenuhnya menjadi bagian dari budaya Nasional; penyanyi popular Chrisye, misalnya, memeluk agama Islam dan menikah dengan orang Minang.

Posisi orang Tionghoa di antara masyarakat Pribumi dalam karya sastra, dan dengan demikian solusi yang ditawarkan para sastrawan untuk "Masalah Cina"-nya Orde Baru sudah lama dibahas. Dalam bukunya Sastra Cina Peranakan dalam Bahasa Melayu, Claudine Salmon (1985) sudah mulai menyinggung hubungan antara orang Pribumi dengan orang Tionghoa sebagaimana direpresentasikan oleh pengarang Tionghoa sendiri. Sementara Allen (2008) melacak posisi orang Tionghoa dalam beberapa karya sastra yang terbit pada tahun 1990-an dan 2000-an. Namun, hasilnya belum terlalu mendalami isi suatu karya sebab penelitian-penelitian serupa cenderung mencari garis besarnya saja.

Dalam konteks ini, ada karya yang cukup menarik, yaitu Di Kaki Bukit Cibalak (1977) yang dikarang Ahmad Tohari, seorang Muslim Jawa yang aktif di dunia pesantren. Novel ini mengisahkan seorang pemuda Jawa, yaitu Pambudi, yang terpaksa meninggalkan Desa Tanggir dan pindah ke Yogyakarta karena terjadi masalah dengan lurah yang korup, Pak Dirga. Karya ini dilengkapi dengan subplot yang mengisahkan bekerjanya Pambudi pada toko milik seorang perempuan Tionghoa, Nyonya Wibawa, serta kisah cinta antara Pambudi dengan Mulyani, anak dari Nyonya Wibawa. Oleh karena itu, meskipun novel ini kerap diteliti sebagai kritik terhadap korupsi dan politik Orde Baru (misalnya dalam Mahayana dkk, 1995: 64), Di Kaki Bukit Cibalak juga wajar diteliti sebagai usaha pengarang menjawab "Masalah Cina"-nya pemerintah.

Strukturalisme genetik, sebuah teori yang pertama kali dikemukakan oleh Lucien Goldmann, merupakan salah satu teori sosiologi sastra. Menurut Faruk (2011: 56), teori ini dibangun atas enam konsep dasar, yaitu fakta kemanusiaan, subjek kolektif, strukturasi, pandangan dunia, pemahaman, dan penjelasan.

Fakta kemanusiaan adalah hasil aktivitas atau perilaku manusia, baik itu tindakannya sebagai individu (yang bersifat naluriah atau libidinal) maupun tindakannya sebagai kolektif (misalnya hubungan sosial, ekonomi, ataupun politik). Fakta kemanusiaan harus dipahami dalam konteks strukturnya sebab ia (dan seluruh struktur) diarahkan untuk mencapai tujuan tertentu; tujuan yang hendak dicapai ini tumbuh sebagai respons subjek kolektif terhadap situasi dan kondisi di sekitarnya.

Subjek kolektif, atau trans-individual, yang dimaksud di sini merupakan satu kesatuan; ia bukan terdiri atas sejumlah individu yang memiliki tujuan dan tindakan masing-masing, tetapi atas bagian-bagian yang bekerja sama untuk mencapai tujuan yang sama. Goldmann memposisikan subjek kolektif sebagai kelas sosial (Faruk, 2011: 63), meskipun bisa juga dimengerti sebagai kekerabatan dan lain-lain. Subjek-subjek kolektiflah yang melakukan strukturasi yang menghasilkan masyarakat, dan juga melahirkan karya sastra yang mampu mencerminkan pandangan dunianya melalui usaha strukturasi.

Pandangan dunia subjek kolektif, yaitu "kompleks menyeluruh dari gagasan-gagasan, aspirasi-aspirasi, dan perasaan-perasaan, yang menghubungkan secara bersama-sama anggotaanggota suatu kelompok sosial tertentu dan yang mempertentangkannya dengan kelompok sosial yang lain" (Faruk, 2011: 66), hadir dalam karya sastra melalui homologi karya sastra dengan masyarakat. Pandangan dunia ini berkembang dalam konteks situasi sosial dan ekonomi 
subjek kolektif yang memilikinya, dan terwujud sebagai suatu kesadaran yang-mungkin (yaitu kesadaran yang merupakan kecenderungan dalam suatu subjek kolektif). Pandangan dunia subjek kolektif ini, dalam konteks karya sastra, terwujud melalui proses strukturasi yang dilakukan oleh subjek kolektif itu sendiri secara imajiner dan melalui penciptaan tokoh-tokoh, objek-objek, dan relasi-relasi secara imajiner.

Struktur karya sastra, sekaligus pandangan dunia yang mendasari penciptaannya, dapat diteliti dengan suatu dialektika antara pemahaman dan penjelasan. Dialektika antara pemahaman, yaitu "usaha pendeskripsian struktur objek yang dipelajari” (Goldmann, 1970: 590, dalam Faruk, 2010: 79), dan penjelasan, yaitu "usaha menggabungkan [struktur objek] ke dalam struktur yang lebih besar" (Goldmann, 1970: 590, dalam Faruk, 2010: 79) tidak dapat dipisahkan dari dialektika antara keseluruhan dan bagian, yaitu antara keseluruhan struktur karya dan bagianbagiannya. Analisis dilakukan melalui siklus, lalu melihat hubungan bagian dengan keseluruhan, dan hubungan keseluruhan dengan bagianbagiannya.

Karena teori strukturalisme genetik bersifat sangat luas, dan dapat mencakup keseluruhan struktur masyarakat dan semua subjek kolektif yang terdapat di dalamnya, untuk penelitian ini data dibatasi pada faktafakta sosial yang memiliki kaitan dengan orang Tionghoa sebagaimana dicitrakan dalam $D i$ Kaki Bukit Cibalak. Unsur yang berkait dengan jurnalistik, korupsi, dan sebagainya, karena tidak terkait dengan masalah yang hendak dijawab, tidak dipertimbangkan. Penelitian dilakukan dengan mencari data (berupa kata, kalimat, dan paragraf) mengenai subjek kolektif dan pandangan dunianya mengenai orang Tionghoa dalam teks Di Kaki Bukit Cibalak serta fakta kemanusiaan dalam teks-teks sekunder. Data ini kemudian diklasifikasikan berdasarkan bagian struktur yang terkait, lalu dianalisis melalui proses dialektik pemahaman dan penjelasan.

\section{Nyonya Wibawa dan Budaya Tionghoa yang Kaku}

Nyonya Wibawa, yang bernama asli Oei Eng Hwa (Tohari, 2001: 107), adalah seorang pemilik toko arloji yang menjadi majikan Pambudi sekaligus ibu dari Mulyani. Dalam perkenalan tokoh ini, sudah jelas ia digambarkan sebagai stereotipe Tionghoa. Dialog pertama (dan, selain beberapa kata seru, terakhir) yang dituturkan Nyonya Wibawa merepresentasikan logat orang Tionghoa yang belum menguasai bahasa Indonesia. Bunyi [r] diganti dengan [1], bunyi [h] dihilangkan, dan kata ya terus diulang, sebagaimana berikut:

“... perintah pertama yang diberikan oleh Nyonya [Wibawa] itu adalah, 'Tolong belsihkan sepeda Mulyani itu. Ini sudah ampel jam tuju, ya! Mulyani musti pigi sekolah, ya. Toko buka jam delapan, ya" (Tohari, 2001: 107).

Logat ini menjadi suatu pembeda awal yang menunjukkan bahwa Nyonya Wibawa tidak ada keinginan untuk mengikuti normanorma nasional Indonesia. Ia mempertahankan suatu logat yang tidak patuh kepada kaidah bahasa Indonesia, dan dengan demikian terus membedakan dirinya dari masyarakat sekitar yang menggunakan bahasa yang lebih baik dengan logat yang umum. Karena ini, Nyonya Wibawa mudah dikenali sebagai sosok Tionghoa yang tidak mengindonesia; dari inilah dapat diketahui bahwa, dalam konstruksi yangmungkin ini, ia menjadi wakil dari semua orang Tionghoa yang membedakan diri mereka.

Dengan sendirinya, pembedaan ini belum menjadi sepenuhnya negatif. Walaupun dari segi tata bahasa pernyataan ini kurang baik, ia tetap dapat dipahami. Namun, dalam karakterisasi selanjutnya sifat tidak baiknya Nyonya Wibawa menjadi semakin menonjol. Saat menyarankan agar Pambudi bekerja di toko arloji itu, Tomo (teman Pambudi yang juga orang Jawa dari desa Tanggir) menjelaskan kebiasaan Nyonya Wibawa dalam mempekerjakan orang: "bekerja pada nyonya itu, bukan hanya melayani toko. Pekerjaanmu 
nanti termasuk juga tugas-tugas kacung, maaf" (Tohari, 2001: 107). Pernyataan Tomo tidak salah, sebab perintah pertama yang diterima Pambudi ialah untuk membersihkan sepeda Mulyani sebelum dia berangkat sekolah - suatu pekerjaan yang biasanya dikerjakan pembantu dan bukan penjaga toko. Pambudi juga harus menyapu, mengepel, dan mengantarkan pembantu berbelanja ke pasar.

Nama Nyonya Wibawa pun menunjukkan sifat dia sebagai orang yang memiliki kekuasaan, sehingga terkesan bahwa kekuasaan yang dimiliki menjadi segala-galanya bagidia-dan, melalui homologi teks dan struktur sosial, orang-orang Tionghoa yang tidak ingin berbaur pada umumnya. Namun, kekuasaan ini terwujud dengan cara merendahkan Pambudi. Ia menyamakan Pambudi, seorang lulusan SMA yang hendak masuk universitas, dengan orang yang tidak terdidik dan tidak berbudaya, seakan dia tidak mungkin keberatan dengan mengurus pekerjaan selain menjaga toko.

Hal ini mempunyai homologi dengan pandangan masyarakat Pribumi terhadap pembisnis Tionghoa di Indonesia. Orang Tionghoa yang berbisnis dinilai hanya mengutamakan uang dan kelancaran usaha mereka, sementara orang Pribumi hanya dianggap sebagai buruh, atau tepatnya tubuh, yang bisa diperintah untuk melakukan apa saja yang diperintah oleh majikan -bahkan meski hal itu tidak termasuk dalam tugas tetap mereka sebagai pegawai. Bahkan, ditarik ke struktur yang lebih luas lagi, ada suatu pandangan bahwa orang Tionghoa seperti Nyonya Wibawa hanya menjadi kaya dengan memeras orang Pribumi, menggunakan mereka, lalu membuang mereka. Dengan kata lain, orang Tionghoa (menurut pandangan dunia yang berlaku dalam Di Kaki Bukit (ibalak) menjadi kaya atas pengorbanan orang Pribumi, seperti halnya Nyonya Wibawa dapat memperlakukan Pambudi sebagai babu untuk kelancaran bisnisnya.

Bahwa orang Pribumi tidak dianggap oleh orang Tionghoa yang tidak berbaur dapat dilihat pula melalui homologi teks, yaitu dalam hubungan Nyonya Wibawa dengan kedua anjing peliharaannya. Sebagaimana dinyatakan di atas, dalam novel Di Kaki Bukit Cibalak Nyonya Wibawa hanya mengutarakan satu perintah kepada Pambudi serta beberapa kali mengutarakan kata seru "Cuh!". Ketika Nyonya Wibawa mengutarakan kata "Cuh" dan meludah (yang menunjukkan rasa bencinya terhadap hubungan Pambudi dan Mulyani), ia selalu bersama anjingnya. Pemilik dan binatang peliharaan selalu berdua, dan karena itu jelaslah bahwa anjing peliharaan tersebut ikut masuk ke toko arloji dan tempat kerja.

Dalam konteks Islam (agama yang dianut Pambudi [Tohari, 2001: 27] sekaligus yang membentuk pandangan dunia subjek kolektif yang menghasilkan novel ini), anjing dinilai sebagai binatang yang kotor. Dalam hadits (setepatnya Muwatta Malik), dinyatakan bahwa memelihara anjing akan mengurangi berkah dari tindakan baik seseorang. Anjing bahkan dianggap menodai seluruh ruang tempat ia berada, dan kalau orang Muslim dijilat anjing, ia harus membersihkan dan menyucikan tubuhnya (Joel, 1987: 687). Oleh karena itu, banyak orang Muslim tidak memelihara anjing, dan menghindari anjing apabila nampak. Dengan memelihara anjing, Nyonya Wibawa menunjukkan rasa tidak pedulinya akan ketidaknyamanan pegawainya yang Muslim ataupun kebudayaannya. Melalui homologi dengan struktur sosial kontemporer, hal ini menyatakan bahwa orang Tionghoa yang masih kokoh memegang kebudayaan Tionghoa tidak memiliki kepedulian kepada orang Pribumi ataupun kebudayaan mereka (baca: kebudayaan nasional).

Namun, pengertian homologi teks dan struktur sosial ini juga menawarkan pengertian yang lain tentang Nyonya Wibawa. Ketika ia meludah dan bersuara "Cuh", anjingnyga juga bersuara: ia menyalak, "Hwuf!". Tindakan yang paralel ini menunjukkan suatu kedekatan batin antara tokoh Nyonya Wibawa dan binatang peliharaannya, tetapi juga bisa dipahami sebagai penyamaan mereka dalam naratif: seperti halnya Nyonya Wibawa lama-kelamaan membenci Pambudi, begitu juga anjing itu membencinya. 
Nyonya Wibawa (atau, dalam struktur sosial luas, orang Tionghoa yang terus berpegang pada kebudayaan tradisional mereka), menurut pandangan dunia ini, menjadi sama dengan anjing; ini membawa implikasi bahwa ia harus disingkirkan, dijauhkan, dan tidak boleh diterima oleh orang baik-baik. Muncullah suatu pesan: mereka yang tidak ingin berbaur harus pergi.

Merendahkan orang Tionghoa yang tidak ingin berbaur bukan hanya dilakukan dengan penyamaan mereka dengan anjing. Dengan berjalannya narasi, Nyonya Wibawa menjadi semakin tidak berwibawa. Ia tidak dapat mencegah perkembangan hubungan antara Mulyani dan Pambudi, sehingga kekuasaan yang dimilikinya di toko arloji tidak terbawa sampai tempat di luar; kekuasaannya terbatas, bukan absolut. Bahkan suaranya, sebagaimana dinyatakan di atas, seakan hilang dan diganti hanya dengan bunyi "Cuh" dan tindakan meludah. Ia tidak dapat, atau tepatnya (mengingat bahwa ia sebenarnya merupakan ciptaan subjek kolektif) tidak diperkenankan untuk mengutarakan posisi dia sendiri. Meskipun ia tidak senang dengan hubungan Pambudi dan Mulyani, ia tidak dapat bertindak secara efektif. Oleh karena itu, nasib dia sepenuhnya tergantung pada pilihan orang lain.

Dalam homologi teks, ini menggambarkan suatu tuntutan dari subjek kolektif, yang semakin mendukung penolakan tradisi'Tionghoa: teks seakan menyatakan bahwa, seperti halnya Nyonya Wibawa yang kehilangan kekuasaan dan hak untuk menentukan masa depannya sendiri, orang Tionghoa yang terus berpegang pada tradisi: apabila mereka tidak mau menghormati dan bahkan mengikuti kebudayaan Pribumi (kebudayaan 'nasional' Indonesia), maka mereka akan kehilangan segala hak untuk menentukan nasibnya sendiri serta kekuasaan untuk membuat suara mereka terdengar dalam dialog yang lebih luas. Hal ini diikuti dengan implikasi bahwa mereka lebih baik menyatu dengan orang Pribumi; ini dieksplorasi lebih lanjut dengan tokoh Mulyani.

\section{Mulyani dan Keinginan untuk Berbaur}

Mulyani, anak dari Nyonya Wibawa, lama-kelamaan memiliki pendirian yang sama sekali berlainan dengan ibunya. Pada awalnya, ia bertindak sebagai majikan dari Pambudi semata ("Pada sore hari biasanya Mulyani ikut ke depan melayani para pembeli. ... Mulyani belum pernah sekali pun berbicara dengan Pambudi, selain mengenai masalah pembayaran dari pembeli misalnya" [Tohari, 2001: 108]). Mereka tidak berinteraksi, dan menjaga jarak selayaknya seorang pegawai dan majikannya (seperti juga halnya Pambudi menjaga jarak dengan Nyonya Wibawa). Pada saat ini belum kelihatan adanya suatu keinginan, apalagi usaha, untuk menyatu; mereka berada dalam dua dunia yang berbeda.

Pada suatu hari, Pambudi melihat Mulyani sedang merasa stress karena tidak bisa menyelesaikan teka-teki silang. Setelah Mulyani putus asa dan keluar, tokoh Pambudilah yang menyelesaikan dan mengirimkan ke kantor koran karena merasa segan dengan Mulyani. Beberapa minggu kemudian Mulyani menerima wesel senilai 2.500 rupiah, dan setelah Pambudi menjelaskan perbuatannya terbukalah jalan komunikasi antara mereka. Semakin lama mereka semakin sering bekerja sama untuk menyelesaikan teka-teki silang, lalu belajar untuk ujian sekolah, lalu jalan-jalan bersama (misalnya, ketika mereka berjanji akan menonton film Mandigo (sic) [Tohari, 2001: 123]). Lama-kelamaan Mulyani jatuh cinta dengan Pambudi, dan (meskipun ia masih mengharapkan perempuan lain) Pambudi mulai jatuh cinta dengan Mulyani.

Bertahun-tahun berlalu, Pambudi dan Mulyani menjadi kakak-adik kelas di universitas. Pada akhir cerita, Mulyani mengakui rasa cinta yang dimilikinya untuk Pambudi. Bukan dengan kata cinta — sebab ia ingin dengar kata cinta dari Pambudi terlebih dahulu (Tohari, 2001: 167)—melainkan melalui tindakannya. Ia "memancarkan getaran-getaran lembut, pulsa nuraniah yang langsung ditangkap oleh jiwa Pambudi" dan "memeluk pemuda itu erat-erat" (Tohari, 2001: 167-68) sehingga maksudnya tersampaikan dan Pambudi 
menyadari apa yang diinginkan Mulyani. Pambudi pun menyampaikan cintanya secara implisit: "diangkatnya wajah Mulyani. Mereka bertatapan. Hati dan jiwa keduanya bertatapan" (Tohari, 2001: 170).

Naratif cinta di atas, kalau ditarik ke struktur sosial masyarakat Indonesia pada tahun 1970-an, dapat beberapa kesamaan dengan perkembangan posisi orang Tionghoa di Indonesia yang menuju pembauran. Hubungan antara Mulyani dan Pambudi yang semula, yang tidak memungkinkan adanya percakapan yang akrab, berhomologi dengan posisi orang Tionghoa dan Pribumi pada masa Belanda. Pada masa kolonial, ada hukum rasial yang menuntut agar orang Tionghoa hanya mengikuti kebudayaan Tionghoa (termasuk dalam soal berpakaian dan lain-lain) dan orang Pribumi hanya mengikuti kebudayaan mereka masing-masing. Meskipun hukum itu mulai dihapus pada abad kedua puluh, dampaknya sudah nyata: orang Tionghoa dan orang Pribumi jarang bergaul, kecuali untuk urusan bisnis.

Homologi ini terus berlangsung ketika Mulyani dan Pambudi mulai berteman karena mengerjakan teka-teki silang bersama, seperti juga halnya orang Tionghoa dan orang Pribumi mulai sering bekerja sama menjelang tahun 1930-an untuk memecahkan masalah kolonialisasi; perusahaan-perusahaan milik orang Tionghoa, seperti koran Sin Po, mendukung kemerdekaan Republik Indonesia dengan menggunakan istilah 'Indonesia' dan mendukung perkembangan pendidikan di Nusantara. Orang Tionghoa seperti Tan Eng Hoa menjadi anggota Badan Penyelidik Usaha Persiapan Kemerdekaan Indonesia, dan Yap Tjuan Bing menjadi anggota Panitia Persiapan Kemerdekaan Indonesia; kedua badan ini melangkah untuk kemerdekaan. Perkembangan selanjutnya, dalam tahun 1950-an, tetap memperlihatkan kerja sama antara orang Tionghoa dan Pribumi di bidang sosial dan politik. Namun, masih terjadi perpisahan antara kedua kelompok ini, seperti dalam masalah kewarganegaraan yang sudah disinggung di atas.
Ketika percintaan Mulyani dan Pambudi ditampakkan, homologi dengan pandanganyang mendukung pembauran orang Tionghoa dalam masyarakat Pribumi, sebagaimana berkembang dalam tahun 1970-an, juga menjadi jelas. Dua sahabat, betapapun akrabnya, tetap ada jarak pemisah antara mereka; mereka tidak dihitung sebagai satu kesatuan (tidak dihitung sebagai keluarga, misalnya), dan tidak juga dituntut untuk selalu bersama seperti halnya orang yang jatuh cinta dan menikah. Demikian pula orang Tionghoa yang bekerja sama dengan orang Pribumi dengan tetap menjaga jarak antara mereka (dengan tidak berbaur); mereka tidak menyatu, melainkan tetap berbeda, meskipun mungkin memiliki tujuan yang sama. Dengan menjadikan Mulyani dan Pambudi sebagai dua orang yang saling jatuh cinta dan mungkin kelak akan menikah, pandangan dunia yang berlaku dalam Di Kaki Bukit Cibalak menekankan bahwa pertemanan antara orang Tionghoa dan Pribumi tidaklah cukup; mereka harus menjadi satu (atau, dengan kata lain, berbaur).

Perkembangan dalam keinginan untuk berbaur ini juga dapat dilihat dari segi fisik Mulyani. Etnisitas dia sebagai orang Tionghoa tidak dapat ditolak, dan justru di awal cerita cintanya hal ini dikontras dengan fisik Pambudi sebagai orang Jawa. Setelah Pambudi mulai berteman dengan Mulyani dan mereka bekerja sama menyelesaikan teka-teki silang, dinyatakan:

"Ada dua tangan yang saling pegang: yang satu putih kekuning-kuningan, yang satu coklat. Ada dua pasang mata yang tibatiba saling pandang: yang sepasang redup dan sipit, yang lainnya bulat dan tajam" (Tohari, 2001: 111).

Mata Mulyani yang sipit dan khas Tionghoa semakin ditekankan setelah Pambudi meninggalkan pekerjaannya di tokoh Nyonya Wibawa untuk menjadi wartawan dengan harian Kalawarta. Pambudi menyatakan bahwa barangkali suatu hari ia akan menulis tentang gadis yang "langsing, berwajah teduh, dan bermata khas Mandarin" (Tohari, 2001: 122-23). Jelas, dari kedua kutipan di atas, 
bahwa mata yang sipit sebagai ciri khas orang Tionghoa yang tidak dimiliki etnis lain menjadi suatu fakta kemanusiaan dalam struktur naratif Di Kaki Bukit Cibalak. Ia merupakan tanda yang khas, yang identik dengan etnis Tionghoanya Mulyani.

Karena itu, signifikanlah bahwa, pada akhir novel, Mulyani justru mengubah wujud matanya demi kelancaran percintaan dia dan Pambudi. Mata yang semula sipit menjadi "berubah, ada garis lipatan kecil di atas bulu matanya. Seperti bukan mata Mandarin" (Tohari, 2001: 162). Ia kemudian menjelaskan bahwa ia menjalani bedah plastik untuk mengubah wujud matanya, supaya tidak kelihatan keturunan Tionghoa. Hal ini, ia jelaskan, semua demi percintaannya dengan Pambudi, supaya mereka bisa menyatu. Ia bahkan menekankan bahwa ia merasa bahwa ia dan Pambudi sama sekali tidak berbeda, apalagi kalau fisik dia dan pakaian dia sudah dijadikan seperti orang Jawa. Kata Mulyani, "Aku sadar dan aku tahu dengan jelas, tak ada beda apa pun antara kau dan aku. Atau setidaknya kau telah mengatakan aku tampak pantas ketika aku berkain kebaya pada saat graduation day dulu" (Tohari, 2001: 169). Kalau Nyonya 'Wibawa' memiliki otoritas seperti yang dijelaskan di atas, 'Mulyani'-dan dengan demikian keinginannya untuk berbaur-bersifat mulya; cita-citanya akan sangat menguntungkan, menurut pandangan dunia yang berlaku.

Ditempatkan dalam struktur sosial yang mendasari pembentukan naratif oleh subjek kolektif, hal ini mencerminkan suatu keinginan orang Tionghoa untuk berbaur dengan orang Jawa (atau, ditarik ke tingkat nasional, orang Pribumi). Keinginan untuk diterima ini seakan-akan mewarnai semua kegiatannya dan harapannya, seakan semua tertuju untuk memungkinkan penyatuan orang Tionghoa dan Pribumi. Pakaian tradisional tidak dipakai. Bahasa Indonesia yang baik dipelajari dan digunakan (perhatikan bahwa Mulyani tidak memiliki logat seperti ibunya). Bahkan secara fisik ia berusaha untuk menyerupai orang Pribumi, dengan menghilangkan ciri yang khas
Tionghoa melalui operasi plastik. Tindakannya menjadi ekstrim, yang mencerminkan adanya suatu keinginan besar untuk berbaur dengan orang Jawa.

Namun demikian, tindakan berbaur ini (seperti halnya cinta Mulyani dan Pambudi) belum tentu dapat dijalani dengan lancar. Ternyata masih ada yang mempertanyakan atau bahkan menolak pembauran orang Tionghoa dan Pribumi, baik darikalangan Tionghoa sendiri maupun Pribumi, seperti juga halnya hubungan Mulyani dan Pambudi dipertanyakan. Ketika Nyonya Wibawa melihat betapa akrabnya anak dan pegawainya, ia "memandang dengan benci. 'Cuh, cuh' dia meludah. Anjingnya berbuat sama, 'Hwuf, hwuf"' (Tohari, 2001: 123); ia, sebagai pemegang kebudayaan Tionghoa yang lama sekaligus pihak yang "berwibawa", keberatan. Ibu Pambudi pun, meskipun tidak sampai benci, masih heran kalau Pambudi bisa punya hubungan akrab dengan "gadis yang kuning dan tampaknya orang kaya" (Tohari, 2001: 166).

Pambudi pun mempertanyakan kelaziman hubungan dia dan Mulyani. Meskipun ia mencintai Mulyani dan hendak bersamanya, Pambudi pun masih punya keraguan apakah mereka bisa sampai menikah. Perbedaan antara mereka, seperti kekayaan, kebiasaan hidup, dan kebudayaan, sangat besar dan sulit diatasi. Pambudi, selaku suara subjek kolektif dalam karya, belum yakin apakah cintanya dapat terwujud, sehingga ia bertanya:

"Rasa cinta hanya tersedia buat bekal perkawinan. Nah, aku hendak mengawini Mulyani? Oh, seribu perbedaan yang harus kusingkirkan sebelum aku memutuskan berbuat demikian. Cinta tidak akan lestari bila berjalan terlalu jauh dari kenyataan. ... [Ia lalu bertanya] 'Mul, apakah kau tidak sadar ada pemisah di antara kita berdua? Bukankah kita berdua lahir dalam keadaan yang serba berbeda?" (Tohari, 2001: 169).

Dari kutipan di atas, nampak bahwa dalam pandangan dunia yang berlaku di $D i$ Kaki Bukit Cibalak masih ada keraguan apakah 
mungkin orang Tionghoa dan orang Pribumi bisa menyatu. Meskipun ada usaha dari pihak orang Tionghoa untuk menjadi bagaikan orang Pribumi, tetap ada perbedaan dalam posisi mereka masing-masing (kebudayaan, agama, posisi sosio-ekonomi, dan lain-lain) serta pandangan masyarakat mengenai perbedaan dua kelompok etnis tersebut. Perbedaanperbedaan ini sangat banyak, sehingga pembauran absolut akan sulit (atau bahkan mustahil) terwujud, dan masih mungkin kalau dikotomi pribumi dan non-pribumi akan tetap dipertahankan. Meskipun demikian, tidak ditawarkan kemungkinan untuk toleransi, atau mengesampingkan perbedaan-perbedaan antara orang Tionghoa dan Pribumi demi kebaikan bersama; hal tersebut akan dinilai tidak mendukung harmoni antar-etnis. Dengan kata lain, menurut pandangan dunia yang ditawarkan Di Kaki Bukit Cibalak, satu-satunya jawaban untuk "Masalah Cina" hanyalah pembauran; kalau hal itu tidak terealisasi, tidak bisa terjadi penyatuan Tionghoa dan Pribumi.

\section{Tionghoa dalam Posisi Perempuan}

Kalaupun memang orang Tionghoa dan orang Pribumi dapat menjadi satu dan tinggal bersama dalam kedamaian, bagaimanakah kedudukan mereka dalam hierarki di Indonesia menurut pandangan dunia yang berlaku dalam Di Kaki Bukit Cibalak? Jawaban ini dapat dilacak dalam kesamaan yang dimiliki Nyonya Wibawa maupun Mulyani, selain etnisitas mereka sebagai orang Tionghoa: mereka sama-sama perempuan. Hal ini bukanlah suatu kebetulan, dan bukanlah karena kepentingan alur semata. Memang, fakta sosial Indonesia pada tahun 1977 tidak akan mendukung hubungan romantis antara laki-laki dengan laki-laki, sehingga tokoh Mulyani tentu akan digambarkan sebagai perempuan. Namun, posisi majikan bisa saja diisi dengan lelaki tanpa menentang fakta sosial yang ada dalam masyarakat tersebut; kenyataan ini dapat dilihat dengan hadirnya tokoh Pak Barkah sebagai pemimpin redaksi harian Kalawarta. Oleh karena itu, dapat disimpulkan bahwa ada suatu alasan, selain kepentingan alur, mengapa pengarang menentukan gender perempuan untuk kedua tokoh ini.

Alasannya menjadi lebih jelas dengan mempertimbangkan fakta sosial yang berkaitan dengan kesetaraan (atau, setepatnya, ketidaksetaraan) gender dalam konteks budaya Jawa. Kebudayaan Jawa, yang turut membentuk pembentuk pandangan dunia subjek kolektif yang menghasilkan karya ini, menuntut agar perempuan menjalani tiga tugas: manak (melahirkan anak), macak (berdandan), dan masak (masak). Meskipun tiga kata ini secara gramatikal menjadikan perempuan sebagai subjek (melalui awalan $m$-), dalam kenyataannya mereka tidak bertindak demi kepentingan mereka sendiri. Manak, atau melahirkan anak, menjamin keberlangsungan kekerabatan sang suami (mengingat bahwa keturunan dinilai dari pihak ayah), dan dengan demikian menguatkan posisi suami dalam pandangan masyarakat dan dalam catatan sejarah. Dengan macak, seorang istri menjadikan dirinya lebih cantik dan, dengan demikian, dapat mempesona suami dan menimbulkan nafsu birahinya; nafsu birahi ini kemudian dipuaskan oleh istri melalui hubungan seksual. Semua hal ini membuat suami merasa lega, atau, dengan kata lain, macak berfungsi untuk menjamin kesehatan mental suami. Sementara, masak merupakan tindakan menyiapkan dan menyediakan makanan untuk suami, yang memenuhi keperluan gizinya. $\mathrm{Hal}$ ini menjamin kesehatan fisik suami.

Sifat mendukung ini nampak dalam hubungan Nyonya Wibawa dengan Pambudi serta hubungan Mulyani dengan Pambudi. Nyonya Wibawa, meskipun (seperti dijelaskan di atas) memanfaatkan tenaga Pambudi dan membenci pegawainya itu, hadir dalam naratif hanya untuk kepentingan Pambudi sendiri. Ia hanya menawarkan pekerjaan yang bisa digunakan untuk perkembangan tokoh utama, serta menyediakan tempat di mana Pambudi bisa berkenalan dengan Mulyani. Meskipun ia tidak masak secara langsung, ataupun memberikan makanan kepada Pambudi, gaji dari Nyonya Wibawa sudah "cukup untuk belanja makan yang sederhana" (Tohari, 2001: 108). 
Pambudi bisa menjamin keberlangsungan fisiknya berkat pekerjaan yang didapat di toko arloji, dan ketika keperluan itu sudah tidak dipenuhi olehnya, Nyonya Wibawa seakan menjadi penghalang bagi perkembangan Pambudi; ketika ia dan Mulyani hendak pergi jalan-jalan, Pambudi mengomentari "selama [Nyonya Wibawa] tidak menyuruh anjingnya merobek betisku" (Tohari, 2001: 123). Namun, pada akhirnya Nyonya Wibawa tidak dapat menghentikan keinginan Pambudi ataupun Mulyani, sehingga penolakannya tidak berarti. Hal ini menunjukkan bahwa, dalam pandangan dunia novel ini, orang Tionghoa yang menolak berbaur pada akhirnya tidak memiliki kekuasaan yang berarti, meskipun mereka berusaha menerapkannya. Pambudi tetap bisa meninggalkannya dan menuju kehidupan yang lebih baik, akan menyatakan bahwa - menurut pandangan dunia yang berlaku dalam $D i$ Kaki Bukit Cibalak - orang Jawa sudah tidak membutuhkan orang Tionghoa yang tidak ingin berbaur dan merendahkan mereka.

Sementara, perlunya perempuan dalam konteks Jawa untuk macak dan masak ditunjukkan pula oleh Mulyani. Kedua hal ini sudah tampak ketika mereka mulai berteman, dan menunjukkan cara Mulyani mendukung kesehatan fisik dan mental Pambudi. Ketika Pambudi menjadi bingung melihat soal tekateki, ia melihat tubuh Mulyani yang cantik dan menggairahkan, sehingga pikirannya jadi terang. Teks mengakui pengaruh fisik Mulyani, dengan merujuk kepada psikologi Sigmund Freud, sebagai berikut:

"Pambudi] menoleh, dan sekali ini ia berani menatap Mulyani dengan jelas. Segar kulit gadis itu. Alis dan matanya khas Mandarin. Tetapi leher itu! Jenjang dan punya kerutan-kerutan halus yang melingkar ... Akhirnya wajah Pambudi menjadi cerah. Masa bodoh dengan teori Sigmund Freud, tetapi karena tatapan Mulyani otaknya menjadi cerah" (Tohari, 2001: 110).

Selain menyegarkan pikiran Pambudi dengan fisiknya yang rupawan (atau, dalam konteks budaya Jawa, dengan macak), Mulyani juga menjamin kesehatan fisik lakilaki yang dicintainya, bukan hanya dengan mempekerjakan dirinya (seperti yang dilakukan ibunya) secara paruh waktu, tetapi juga dengan memberikan pangsit sebagai tanda terima kasih ketika Pambudi membantu Mulyani menjawab teka-teki silang (Tohari, 2001: 110) serta keripik usus ayam ketika Pambudi berkunjung ke rumah (Tohari, 2001: 122). Selain itu, ia masih meyakinkan ibunya untuk tetap mempekerjakan Pambudi sebagai guru les dan pegawai paruh waktu (Tohari, 2001: 112), sehingga Pambudi tetap menerima dukungan finansial untuk merawat dirinya sendiri. Mulyani, yang menjadi wakil dari orang Tionghoa yang ingin berbaur, tetap diposisikan sebagai pendukung belaka; meskipun ia bisa bertindak, tindakannya itu sepenuhnya untuk mendukung tokoh utama, Pambudi. Ia seakan tidak eksis di luar hubungannya dengan tokoh Jawa itu.

Ketika posisi Mulyani dan Pambudi ditarik ke dalam konteks struktur masyarakat yang melahirkan karya Di Kaki Bukit Cibalak, nampak bahwa masyarakat Tionghoa (dalam pandangan dunia ini) bukan hanya belum tentu dapat menyatu dengan masyarakat Pribumi, tetapi kalaupun kesatuan itu menjadi nyata, mereka tetap memiliki posisi sekunder, tetap sama tetapi berbeda. Orang Tionghoa seakan hanya diperkenankan mendanai perkembangan orang Pribumi dan mendukung mereka secara finansial (seperti yang dilakukan oleh Nyonya Wibawa dan Mulyani untuk Pambudi), atau menjamin kesehatan mental dan fisik orang Pribumi (seperti yang dilakukan Mulyani untuk Pambudi), tanpa memiliki kekuasaan sendiri; mereka yang hendak menerapkan kekuasaan, seperti Nyonya Wibawa yang menolak Pambudi sebagai teman anaknya, justru menjadi penghalang. Sementara itu, meskipun Mulyani bisa menolak tuntutan dari ibunya (sama seperti orang Tionghoa bisa menolak kekuasaan kebudayaan) ia tetap tidak bisa menerapkan kekuasaan yang sepenuhnya, setidaknya selama ia bercinta dengan Pambudi. Akhirnya, pembauran yang ditawarkan oleh 
Di Kaki Bukit Cibalak hanyalah pembauran semu, yang masih menerapkan batas antara Tionghoa dan Pribumi; tidak ada pembauran yang sepenuhnya mampu menghapus dikotomi antara mereka.

\section{Kesimpulan}

Sebagaimana ditunjukkan di atas, selain merupakan kritik terhadap korupsi dan penyalahgunaan kekuasaan (Mahayana dkk, 1995: 64) novel Di Kaki Bukit Cibalak karya Ahmad Tohari juga merupakan suatu usaha untuk memecahkan "Masalah Cina"nya pemerintah Orde Baru. Adanya masalah ini, serta polemik mengenai kedudukan orang Tionghoa dalam masyarakat Indonesia, merupakan suatu fakta kemanusiaan pada tahun 1977-an ketika karya ini dihasilkan. Fakta kemanusiaan inilah yang menjadi dasar dari hadirnya tokoh Nyonya Wibawa dan Mulyani dalam teks, serta hubungan tokoh tersebut dengan keseluruhan struktur teks serta unsurunsur lainnya.

Pada akhir teks, tokoh-tokoh ini (sekaligus hubungan mereka dengan tokoh lain) adalah metonimi yang mencerminkan apa yang, menurut subjek kolektif yang menghasilkan teks (yang diwakili Ahmad Tohari), merupakan jalan terbaik untuk memecahkan "Masalah Cina". Nyonya Wibawa (sebagai wakil orangorang yang masih kaku memegang sifat dia yang khas Tionghoa, antara lain logat dan kebiasaan memelihara anjing) tidak dapat menjalankan hubungan yang akrab dengan orang Pambudi (sebagai wakil orang Jawa); ia akan selamanya menjadi orang luar, yang tidak dapat menjalankan kerja sama. Sementara, Mulyani (sebagai wakil orang-orang Tionghoa yang mau berbaur, misalnya dengan menggunakan bahasa Indonesia yang baik dan mendekatkan dirinya pada orang Jawa) mempunyai harapan untuk masa depan yang lebih gemilang bersama Pambudi yang dicintainya. Ketika metonimi ini dibongkar, pandangan subjek kolektif sudah jelas: orang Tionghoa hanya bisa berbahagia apabila mereka berbaur secara aktif dengan masyarakat Pribumi. Itu pun belum tentu menjamin kebahagiaan, sebab masih ada kemungkinan bahwa orang Pribumi akan menolak mereka.

Namun, dengan mencitrakan orang Tionghoa sebagai orang perempuan dalam konteks kebudayaan Jawa, posisi mereka tidak setara dengan orang Jawa. Seperti halnya perempuan tidak memiliki hubungan setara dengan laki-laki dalam konteks Jawa, orang Tionghoa dalam novel ini tidak memiliki hubungan setara dengan laki-laki. Seperti dalam jawaban "Masalah Cina" yang digunakan Orde Baru, orang Tionghoa dalam pandangan dunia yang ditawarkan Di Kaki Bukit Cibalak disamakan, tetapi juga tetap dibedakan. Mereka dituntut untuk memiliki adat istiadat yang sama dengan orang Jawa (baca, Pribumi), tetapi tidak mendapatkan hak dan kekuasaan yang sama. Akhirnya, mereka tidak dapat memperjuangkan nasibnya sendiri, tetapi hanya diperbolehkan mendukung kemakmuran dan perkembangan orang Pribumi saja.

\section{Daftar Pustaka}

Allen, Pamela. 2008. "Penghayatan Lintas Budaya: Pribumi Menyoroti Tionghoa dalam Sastra Indonesia". Susastra 7. Vol. 4. No. 1. Hal. 32-42.

Goldmann, Lucien. 1970. "The Sociology of Literature: Status and Problems of Method", dalam Milton C. Albrecht (peny.), The Sociology of Art and Literature. New York: Praeger Publisher.

Faruk. 2012. Pengantar Sosiologi Sastra dari Strukturalisme Genetik Sampai PostModernisme. Yogyakarta: Pustaka Pelajar.

Joel, B. 1987. "Kalb". dalam Houtsma, M Th (peny.). E. J. Brill's first encyclopaedia of Islam 1913-1936 Volume 4. Leiden: E. J. Brill.

Mahayana, Maman S, Oyon Sofyan, dan Achmad Dian. 1995. Ringkasan dan Ulasan Novel Indonesia Modern. Jakarta: Grasindo.

Tan, Mely G. 2008. "The Ethnic Chinese in Indonesia: Issues of Identity". Dalam Etnis Tionghoa di Indonesia. Jakarta: Yayasan Obor Indonesia. Hal. 156-193.

Tohari, Ahmad. 2001. Di Kaki Bukit Cibalak. Jakarta: Gramedia.

Salmon, Claudia. 1985. Sastra Cina Peranakan dalam Bahasa Melayu. Jakarta: Balai Pustaka. 